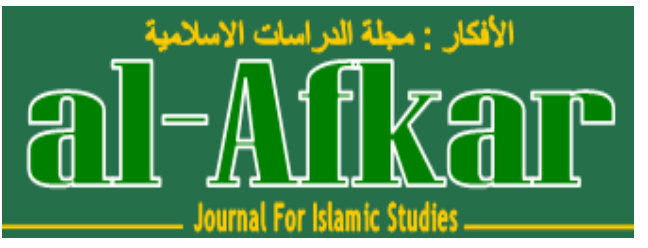

Vol. 2, No. 2, July 2019

P-ISSN : 2614-4883; E-ISSN : 2614-4905

https://al-afkar.com/index.php/Afkar_Journal/issue/view/4

DOI: https://doi.org/10.31943/afkar_journal.v4i1.57

\title{
IMPLEMENTASI PENDIDIKAN KARAKTER DALAM PEMBELAJARAN PENDIDIKAN AGAMA ISLAM DI SEKOLAH MUHAMMADIYAH
}

\author{
Ali Miftakhu Rosyad \\ Fakultas Agama Islam Universitas Wiralodra \\ E-Mail: miftakhurosyad@gmail.com
}

\begin{tabular}{|c|c|c|}
\hline Received & Revised & Accepted \\
\hline 3 Juny 2019 & 20 Juny 2019 & 1 July 2019 \\
\hline
\end{tabular}

\section{THE IMPLEMENTATION OF CHARACTER EDUCATION THROUGH LEARNING OF ISLAMIC RELIGION EDUCATION IN MUHAMMADIYAH SCHOOL}

\begin{abstract}
:
This study is aimed to identify (1)the planing of character education in Islamic religion education; (2) the implementing of character education in Islamic religion education; and (3) the evaluating of character education in Islamic religion educatiom. The study was pursued the qualitative research with kind of case study. The subjects were the principal, teachers, and students. The determination of the subjects was done by using the purposive technique by selecting a number of respondents who are tailored to the purpose of this research. The data were collected through non-participant observation, in-depth interviews and documentation. The technique of data analysis refers to the steps of data analysis proposed by Mills and Heberman with interactive models. The results showed that (1) in the process of planning the school has the development program of school culture to implement student character values which actualized through learning activities; (2) in the implementation of character education actualized by giving good example, admonition, notification, punishment, and task; and (3) based on assessing result showed that the character values that have been actualized in the daily behavior of the students of Muhammadiyah School in Juntinyuat are
\end{abstract}


democracy values, religious, cooperation, social care, respect/honor, and responsible. This study is expected to provide contributions for social studies teachers in Indramayu district as an actualization internalization of character values through school culture.

Keywords: character education, charachter values, and Islamic religion education.

\begin{abstract}
Abstrak:
Penelitian ini bertujuan untuk mengidentifikasi (1) perencanaan pendidikan karakter dalam pembelajaran PAI; (2) penerapan pendidikan karakter dalam pembelajaran PAI; dan (3) evaluasi pendidikan karakter dalam pembelajaran PAI. Penelitian ini merupakan penelitian kualitatif dengan jenis studi kasus. Subjek penelitian adalah kepala sekolah, guru, dan siswa. Penentuan subjek dilakukan dengan menggunakan teknik purposive dengan memilih sejumlah responden yang disesuaikan dengan tujuan penelitian ini. Data dikumpulkan melalui observasi non-partisipan, wawancara mendalam dan dokumentasi. Teknik analisis data mengacu pada langkah-langkah analisis data yang diusulkan oleh Mills dan Heberman dengan model interaktif. Hasil penelitian menunjukkan bahwa (1) dalam proses perencanaan sekolah memiliki program pengembangan budaya sekolah untuk mengimplementasikan nilai-nilai karakter siswa yang diaktualisasikan melalui kegiatan pembelajaran; (2) dalam pelaksanaan pendidikan karakter diwujudkan dengan memberikan contoh yang baik, peringatan, pemberitahuan, hukuman, dan tugas; dan (3) berdasarkan hasil penilaian menunjukkan bahwa nilai-nilai karakter yang telah diaktualisasikan dalam perilaku sehari-hari siswa Sekolah Muhammadiyah Se-Kecamatan Juntinyuat adalah nilai-nilai demokrasi, religius, kerjasama, kepedulian sosial, saling menghargai/ menghormati, dan bertanggung jawab. Penelitian ini diharapkan dapat memberikan kontribusi bagi guru IPS di Kabupaten Indramayu sebagai aktualisasi internalisasi nilai-nilai karakter melalui budaya sekolah.
\end{abstract}

Kata Kunci: pendidikan karakter, nilai-nilai karakter, dan pembelajaran PAI.

\title{
Pendahuluan
}

Pendidikan mempunyai definisi yang luas, yang mencakup semua perbuatan dan semua usaha dari generasi tua untuk mengalihkan nilai-nilai serta melimpahkan pengetahuan, pengalaman, kecakapan, dan keterampilan pada generasi. Dalam hal ini pendidikan nasional membawa misi untuk mengembangkan karakter peserta didik sebagaimana dijelaskan oleh Derlina Sabani \& Satria Mihardi ${ }^{1}$ bahwa.

The National Education aims to build human character that is faithful and devoted to God Almighty, noble, healthy, intelligent, knowledgeable, capable, creative, independent, and become responsible and democratic citizens. Based on national

\footnotetext{
${ }^{1}$ S Mihardi, “Improved Characters and Student Learning Outcomes Through Development of Character Education Based General Physics Learning Model," Education 6, no. 21 (2015): 162-71.
} 
education goals it is clear that character education should be carried out deliberately, systematically and continuously in formal and informal education.

Menurut Muchlas Samani \& Haryanto² pendidikan karakter adalah proses pemberian tuntuan kepada peserta didik untuk menjadi manusia seutuhnya yang berkarakter dalam dimensi hati, pikiran, raga, rasa, dan karsa. Pendidikan karakter sering dinamai pendidikan budi pekerti plus yang bertujuan mengembangkan kemampuan peserta didik agar mampu memberikan keputusan moral dan mewujudkan kebaikanya itu dalam kehidupan sehari-hari dengan sepenuh kesadaran dan tanggung jawab.

Menurut Diana S.P. \& Abdul Malek R. ${ }^{3}$ menjelaskan bahwa, “Character education is the concept of the development of the moral consciousnessof students , emerging from psychology, social learning, and cognitive development framework. Maksudya adalah pendidikan karakter merupakan konsep dari pengembangan kesadaran moral pada peserta didik, yang muncul dari psikologi, interaksi sosial, dan pengembangan kognitif. Jadi, pendidikan karakter adalah bagian yang tidak terpisahkan dari pendidikan itu sendiri. Pendidikan karakter memiliki peranan sebagai pendukung pembelajaran dari lingkungan sosial yang telah dikembangkan, karena pendidikan karakter selalu berusaha memberikan kesadarakn kepada peserta didik tentang lingkunganya sehingga peserta didik mampu membuat keputusan moral yang baik.

Orang berkarakter itu berarti orang yang berkepribadian, berperilaku, bersifat, bertabiat, atau berwatak. Berdasarkan definisi singkat itu bisa kita pahami bahwa karakter merupakan watak dan sifat-sifat seseorang yang menjadi dasar untuk membedakan seseorang dengan yang lainnya. Berdasarkan pengertian tersebut juga bisa kita pahami bahwa karakter itu identik dengan kepribadian. Adapun kepribadian merupakan ciri, karakteristik, atau sifat khas diri seseorang yang bersumber dari bentukan-bentukan yangg diterima dari lingkungan, misalnya keluarga masa kecil, dan bawaan sejak lahir ${ }^{4}$.

Thomas Lickona ${ }^{5}$ memberikan definisi yang sangat lengkap mengenai karakter. Menurut Lickona, karakter adalah "A reliable inner disposition to respond to situations in a morally good way." Lickona juga menambahkan bahwa, "Character so conceived has three interelated parts: moral knowing, moral feeling, and moral behavior" 6 . Karakter merupakan sebuah identitas yand dapat membendakan antara individu yang satu dan individu yang lainya. Dalam bukunya William Damon ${ }^{7}$ menjelaskan bahwa "Charachter as an individual's set psychological characteristics that affect that person's ability and inclination to function morally". Maksudnya dari

\footnotetext{
${ }^{2}$ Muchlas Samani Hariyanto, “Konsep Dan Model Pendidikan Karakter," Bandung: PT Remaja Rosdakarya Offset, 2011.

${ }^{3}$ Diana Septi Purnama, "Character Education and Personal Social Guidance Counseling and Its Effects on Personal Social Competences," JOURNAL OF EDUCATION 7, no. 1 (2014).

${ }^{4}$ Doni Koesoema, Pendidikan Karakter: Strategi Mendidik Anak Di Zaman Global, Jakarta: Grasindo, 2007.

${ }^{5}$ Thomas Lickona, Educating for Character: How Our Schools Can Teach Respect and Responsibility (Bantam, 2009).

${ }^{6}$ Lickona.

${ }^{7}$ William Damon, Bringing in a New Era in Character Education (Hoover Press, 2013).
} 
kalimat tersebut adalah Karakter sebagai cirikhas individu yang merupakan karakteristik psikologis yang mempengaruhi kemampuan dan kecenderungan orang tersebut untuk membut keputusan moral serta mempertanggung jawabkanya. Karakter terdiri dari karakteristik yang mengarahkan seseorang untuk melakukan hal yang benar atau tidak melakukan hal yang benar.

Pendidikan karakter bukan sekedar mengenalkan nilai-nilai karakter kepada siswa, akan tetapi sistem juga harus mampu menginternalisasikan nilai-nilai agar tertanam dan berfungsi sebagai muatan hati nurani sehingga mampu membangkitkan penghayatan tentang nilai-nilai (etos) bahkan sampai pada pengamalannya dalam kehidupan sehari-hari (patos). Nilai-nilai yang telah menjadi muatan hati nurani inilah yang pada waktunya akan berfungsi sebagai penyaring dan penangkal manakala terjadi pertemuan antarnilai yang saling berbenturan. Nilainilai inilah yang selanjutnya menyusun ketahanan mental dan moral, khsusunya jika terjadi pertemuan antarnilai yang berbenturan. Namun, realita seringkali menunjukan bahwa gagasan dan konsep pendidikan yang bagus sering terhenti pada arus wacana dan idealisme semata lantaran tidak menyentuh hingga ke tahap implementasi atau aplikasi ${ }^{8}$.

Lebih lanjut lagi berkaitan dengan penanaman pendidikan karakter Kamarudin $\mathrm{SA}^{9}$ menjelaskan sebagai berikut.

Character education is important for the growth of a human individual as a whole and should be done early. But that does not mean if you do not accommodate basic education of character building, educational institutions also felt no need to conduct it. It is important for an educational institution to not only pay attention to the needs of the academic competence of students, but also the character development so that graduates become graduates who are prepared academically and good character.

Definisi tentang pentingnya pendidikan karakter juga diperkuat oleh Maryono ${ }^{10}$ sebagai berikut.

Character is the way of thinking and peoples' behaviors for living and cooperating in their environment or society. The person who has good character is being able in making decision and having high responsibilities. On its application, the character building is the priority of the Indonesia government policy. Character education is the basic in implementing the vision in national building, namely: creating a society in high moral value, etic codes, high culture, and based on "Pancasila". Education of character is the education which developing the Indonesian cultures and moral values to the students, so they will have high moral values and implement them in their society as the religious, honest, discipline, nationalist, productive, and creative citizens.

\footnotetext{
${ }^{8}$ Maksudin Maksudin, “Pendidikan Karakter Nondikotomik (Upaya Membangun Bangsa Indonesia Seutuhnya)," Jurnal Pendidikan Karakter, no. 2 (2013).

${ }^{9}$ Syamsu A Kamaruddin, "Character Education and Students Social Behavior," Journal of Education and Learning 6, no. 4 (2012): 223-30.

${ }^{10}$ Maryono, "The Implementation Of Character Education Policy At Junior High Schools And Islamic Junior High Schools In Pacitan - International Journal of Education and Research PDFwww.ljern.Com > 2015 > May2015," International Journal of Education and Research 3, no. 5 (2015): 267-74.
} 
Selain itu Alex Agboola \& Kaun Chen Tsai" menjelaskan bahwa "Character education is deliberate attempts to promote the development of values character student such as respect for others, justice, civic virtue and citizenship, and responsibility for self and others in schools". Maksudnya pendidikan karakter adalah usaha yang disengaja untuk memajukan pengembangan karakter dan nilai karakter seperti rasa hormat terhadap orang lain, keadilan, kebajikan, kewarganegaraan, dan tanggung jawab untuk diri sendiri dan orang lain di sekolah. Pendidikan karakter lebih efektif dalam kondisi mendorong siswa dengan memberikan contoh karakter yang baik dan diperkuat oleh sekolah dan guru.

Sekolah merupakan wahana pengembangan pendidikan karakter yang sangat penting. Guru dan pendidik mempunyai tanggung jawab yang sangat besar dalam menghaskan generasi yang berkarakter, berbudaya, dan bermoral. Guru merupakan ujung tombak atau mesin penggerak pendidikan karakter. Jadi, guru memiliki peran dan kedudukan yang strategis dalam pendidikan karakter sesuai dengan amanat Undang-Undang Nomor 14 Tahun 2005 Tentang Guru dan Dosen Pasal 1 ayat (1) menyatakan bahwa guru sebagai pendidik profesional mempunyai tugas utama mendidik, mengajar, membimbing, mengarahkan, melatih, menilai dan mengevaluasi peserta didik pada pendidikan anak usia dini, pada jalur pendidikan formal, pendidikan dasar, dan pendidikan menengah ${ }^{12}$.

Berdasarkan beberapa konsep diatas pendidikan karakter merupakan usaha sadar dan terencana untuk membentuk watak, motivasi, sikap, dan nilai-nilai pada peserta didik secara sistematis dan berkesinambungan. Dalam implementasi, internalisasi, dan aktualisasinya pendidikan karakter memerlukan keteladanan dari pendidik dan orang yang dianggap lebih dewasa. Pendidikan karakter tanpa adanya keteladanan akan menjadi sia-sia. Karena, karakter adalah modalitas utama peserta didik untuk hidup di zaman yang hiper kompetisi seperti zaman sekarang.

Pengembangan kurikulum 2013 menjadi sebagai langkah lanjutan untuk menyempurnakan kurikulum sebelumnya, dengan memadukan moral knowing, moral feeling, dan moral action. M. Fadlillah ${ }^{13}$ mengemukakan bahwa landasan pengembangan Kurikulum 2013 yang menentukan corak dan bentuk kurikulum, terdiri dari landasan filosofis, landasan yuridis dan landasan konseptual. Landasan filosofis berbasis pada nilai-nilai luhur, nilai akademik, kebutuhan siswa dan masyarakat serta kurikulum berorientasi pada pengembangan kompetensi. Landasan yuridis pengembangan Kurikulum 2013 yaitu suatu landasan yang digunakan sebagai payung hukum dalam penyusunan dan pengembangan kurikulum yang mengacu pada UUD 1945, UU Nomor 20 Tahun 2003, Rencana Pembangunan Jangka Menengah Nasional (RPJMN) 2010 - 2014 sektor pendidikan, PP No. 19 Tahun 2005, INPRES Nomor 11 Tahun 2010. Landasan konseptual

\footnotetext{
${ }^{11}$ Alex Agboola and Kaun Chen Tsai, "Bring Character Education into Classroom," European Journal of Educational Research 1, no. 2 (2012): 163-70.

${ }^{12}$ Suryatri Darmiatun Daryanto, "Implementasi Pendidikan Karakter Di Sekolah," Yogyakarta: Gava Media, 2013.

${ }^{13}$ Muhammad Fadlillah, "Implementasi Kurikulum 2013 Dalam Pembelajaran Sd/Mi, Smp/Mts, \& Sma/Ma," Yogyakarta: Ar-Ruzz Media 144 (2014): 15.
} 
memperhatikan prinsip relevansi pendidikan, kurikulum berbasis kompetensi dan karakter, pembelajaran kontekstual, pembelajaran aktif dan penilaian yang valid, utuh, dan menyeluruh.

Kurikulum harus dikembangkan dengan berbagai pendekatan dan pertimbangan yang holistic. Dalam hal ini Maya Bialik, Michael Bogal, et $\mathrm{al}^{14}$ menjelaskan sebagai berikut.

A holistic approach to deeply redesigning the curriculum, by offering a complete framework across the four dimensions of an education: knowledge, skills, character, and metacognition. Knowledge must strike a better balance between traditional and modern subjects, as well as interdisciplinarity, skills relate to the use of knowledge, and engage in a feedback loop with knowledge. Character qualities describe how one engages with, and behaves in, the world. Metacognition fosters the process of selfreflection and learning how to learn, as well as the building of the other three dimensions. Dibawah ini akan dijelaskan gambaran mengenai keterkaitan antara pengetahuan, karakter, dan skill secara sistematis sebagai berikut.

Pendidikan agama ilsam memiliki batasan makna secara filosofis sebagaimana dikatakan oleh Waghid ${ }^{15}$ A philosophy of Islamic education can most appropriately be framed according to threeinterrelated concepts: tarbiyyah (rearing or nurturing), ta'lim (learning) and ta'dib (good-ness). Now considering that both the Qur'a'n and Sunnah (the primary sources of Islamic education) call for the unity of the Muslim. community, it can be claimed that interdependence and consensus are highly prized in Islamic practices-an idea which has some connection with reaching a shared compromise and finding shared commonalities. In this way a philosophy of Islamic education has the potential to cultivate a collective community-an idea constitutive of democratic citizenship education. But this collective community-what Muslims would refer to as ummah can be attained by giving consideration to 'khtilaf (dissagrement).

Berdasarkan pemaparan tersebut, secara filosofis materi pendidikan agama islam harus menyentuh pada aspek pengetahuan, sikap, dan ketrampilan. Pada kompetensi sikap melalui pembelajaran Pendidikan Agama Islam perlu dikembangkan kompetensi sikap spiritual dan sikap sosial yang telah dirumuskan oleh Kementrian Pendidikan dan Kebudayaan agar siswa dapat mengaktualisasikan amal shalih dalam kehidupan individu dan sosial.

Sementara itu pengertian lebih spesifik tentang Pendidikan Agama Islam diberikan Muhaimin ${ }^{16}$, yakni sebagai usaha sadar, terencana, suatu kegiatan bimbingan, pengajaran dan atau latihan yang dilakukan secara berencana dan sadar untuk meningkatkan keyakinan, pemahaman, penghayatan dan pengamalan ajaran agama Islam dari peserta didik di sekolah.

\footnotetext{
${ }^{14}$ Maya Bialik et al., "Character Education for the 21st Century: What Should Students Learn," Center for Curriculum Redesign. Boston: Massachusetts, 2015, 23-180.

${ }^{15}$ Yusef Waghid, "Islamic Education and Cosmopolitanism: A Philosophical Interlude," Studies in Philosophy and Education 33, no. 3 (2014): 329-42.

${ }^{16}$ Muhaimin, Pemikiran Dan Aktualisasi Pengembangan Pendidikan Islam (Rajawali Pers, 2011).
} 
Dala konsteks pendidikan formal sebagaimana dikemukakan oleh Zakiyah Darajdat yang dikutip oleh Hakim ${ }^{17}$, "Pendidikan agama Islam adalah suatu usaha untuk membina dan mengasuh peserta didik agar senantiasa dapat memahami ajaran Islam secara menyeluruh, lalu menghayati tujuan, yang pada akhirnya dapat mengamalkan serta menjadikan Islam sebagai pandangan hidup.

Dengan demikian pembelajaran PAI dapat diartikan sebagai upaya membuat peserta didik dapat belajar, terdorong belajar, mau belajar dan tertarik untuk terus menerus mempelajari apa yang teraktualisasikan dalam Kurikulum 2013 Pendidikan Agama Islam sebagai kebutuhan peserta didik secara menyeluruh yang mengakibatkan beberapa perubahan yang relatif tetap dalam tingkah laku seseorang baik dalam kognitif, efektif dan psikomotorik.

Pemaknaan pembelajaran pendidikan agama Islam merupakan bimbingan menjadi muslim yang tangguh dan mampu merealisasikan ajaran Pendidikan Agama Islam yang berupa sikap spritual, sikap sosial, nilai-nilai, norma, akhlakul karima dan lain sebagainya dalam kehidupan sehari-hari sehingga menjadi insan kamil. Untuk itu penanaman nilai-nilai dalam pembelajaran PAI sangat penting dalam membentuk dan mendasari peserta $\operatorname{didik}^{18}$. Dengan penanaman pembelajaran PAI sejak dini diharapkan mampu membentuk pribadi yang kokoh, kuat dan mandiri untuk berpedoman pada agama Islam.

Sebagai suatu aktifitas yang dilakukan dari semenjak lahir sampai liang lahat (HR. Ibnu Majah) pendidikan mestilah senantiasa dilakukan pembaruan (inovasi). Inovasi sebagai sesuatu yang dipersepsikan baru dalam gagasan, praktik ataupun objek yang disadari atau tidak oleh seseorang atau kelompok untuk diadopsi yang diterapkan melalui tahapan tertentu yang dimaksudkan untuk mengatasi kebutuhan/masalah seseorang atau kelompok. Dalam definisi lain inovasi tidak hanya berupa ide/gagasan, praktik atau objek yang dipersepsikan baru tetapi juga berbeda (difference) dari sebelumnya atau lainnya. Hal berbeda inilah yang kemudian menjadi nilai tambah (value added) bagi suatu inovasi ${ }^{19}$.

Selain itu, untuk membentengi bangsa ini dengan nilai-nilai luhur dan nilainilai moral agama. Sementara itu, pendidikan agama yang diharapakan mampu memberikan solusi dan diajadikan sebagai basis penanaman nilai-nilai moral malah mengalami kondisi yang menyedihkan. Pendidikan agama sebagai satu sub sistem pendidikan nasional tidak lebih hanya sebagai pelengkap yang bersifat marginal dan tetrkesan terpisah dari keilmuan yang lain. Sepanjang sejarahnya, pendidikan agama tidak pernah mengalami sentuhan yang serius untuk dikembangkan sesuai dengan tuntutan perubahan kehidupan yang selalu berkembang dan berjalan maju. Ia hanya diajarkan untuk memenuhi tuntutan kondisi sehingga nyaris tidak mengalami

\footnotetext{
${ }^{17}$ Lukman Hakim, "Pengembangan Media Pembelajaran PAI Berbasis Augmented Reality," Lentera Pendidikan: Jurnal Ilmu Tarbiyah Dan Keguruan 21, no. 1 (2018): 59-72.

${ }^{18}$ Ali Miftakhu Rosyad, "Al-Afkar, Journal for Islamic Studies URGENSI INOVASI PEMBELAJARAN DALAM PENDIDIKAN AGAMA ISLAM AI-Afkar, Journal for Islamic Studies THE URGENCY OF LEARNING INNOVATION ON ISLAMIC RELIGIOUS STUDY" 3, no. 1 (2019), https://doi.org/10.5281/zenodo. 2546882.

${ }^{19}$ Titin Nurhidayati, "Inovasi Pembelajaran PAI Berbasis Multiple Intelligences," Jurnal Pendidikan Agama Islam (Journal of Islamic Education Studies) 3, no. 1 (2015): 23-56.
} 


\section{Ali Miftakhu Rosyad}

Implementasi Pendidikan Karakter dalam......

perubahan yang begitu signifikan. Sehingga wajar dalam pelaksanaan pendidikan agama syarat dengan kelemahan- kelemahan ${ }^{20}$.

Pendidikan karakter merupakan salah satu solusi dan trobosan untuk memecahkan permasalahan bangsa yang telah lama mengalami kirisis moral, sebagaimana diungkapkan oleh Mulyasa ${ }^{21}$ pendidikan karakter memiliki tujuan untuk meningkatkan mutu proses dan hasil pendidikan yang mengarah pada pembentukan karakter dan akhlak mulia peserta didik secara utuh, terpadu dan seimbang, sesuai dengan standar kompetensi lulusan pada setiap satuan dan jenjang pendidikan. Dalam pandangan Ki Hadjar Dewantara ${ }^{22}$ pendidikan karakter seharusnya memperhatikan keseimbangan cipta, rasa, dan karsa tidak hanya sekedar proses alih ilmu pengetahuan saja atau transfer of knowledge, tetapi sekaligus pendidikan juga sebagai proses transformasi nilai (transformation of value). Dengan kata lain pendidikan adalah proses pembetukan karakter manusia agar menjadi sebenar-benar manusia.

Melihat situasi dan kondisi sosial yang terjadi sekarang menunjukan bahwa sebagian siswa mengalami dekadensi moral yang negatif dipengaruhi juga oleh penggunaan teknologi informasi yang tidak tepat yang berkembang sangat pesat di negeri ini. Contohnya peserta didik terekpos oleh budaya barat yang meniru cara berpakaian yang tidak sesuai dan pergaulan bebas. Pada sisi lain, pengaruh teknologi pada aspek positif mengembangkan ${ }^{23}$ informasi dan komunikasi yang menguntungkan bagi siswa, guru, karyawan dan kepala sekolah.

Permasalahan pendidikan karakter yang bersifat temporer adalah kebijakan pendidikan di Indonesia juga lebih mementingkan aspek kecerdasan otak, walaupun belakangan ini pentingnya pendidikan budi pekerti menjadi bahan pembicaraan hangat $^{24}$. Kebijakan tersebut telah menyimpang jauh dari amanat tujuan pendidikan nasional dan pancasila karena hanya mengembangkan aspek kognitif sehingga melupakan aspek afektif dan psikomotoriknya. Pendidikan karekter atau budi pekerti plus bisa dijadikan solusi untuk membentuk lulusan yang cerdas dan berkarakter mulia ${ }^{25}$.

Ditengah terjadinya degradasi moral yang semakin akut seperti saat ini, tidak semua siswa mengalami hal yang sama. Akan tetapi, dibalik merosotnya moral ini masih ada yang menjunjung tinggi nilai-nilai karakter terpuji dalam kehidupan sehari-hari. Berdasarkan hasil pra survei, peneliti menemukan bahwa ada salah satu

\footnotetext{
${ }^{20}$ Wuri Soedjatmiko, "Pendidikan Tinggi Dan Demokrasi” Dalam Menggagas Paradigma Baru Pendidikan; Demokratisasi, Otonomi, Civil Society, Globalisasi, Ed," Sindhunata. Yogyakarta: Kanisius, 2000.

${ }^{21}$ H E Mulyasa, "Manajemen Pendidikan Karakter, Cet," V, Jakarta: Bumi Akara, 2013, 165.

${ }^{22}$ Ki Hadjar Dewantara, "Pendidikan Dan Kebudayaan," Yogyakarta. Majelis Luhur Persatuan Taman Siswa, 1977.

${ }^{23}$ Ali Miftakhu Rosyad, "The IMPLEMENTASI NILAI-NILAI MULTIKULTURALISME MELALUI PEMBELAJARAN PENDIDIKAN AGAMA ISLAM (THE IMPLEMENTATION OF MULTICULTURALISM VALUES THROUGH LEARNING OF ISLAMIC RELIGION EDUCATION)," Risâlah, Jurnal Pendidikan Dan Studi Islam 5, no. 1 (2019): 1-18.

${ }^{24}$ Darmiyati Zuchdi, Zuhdan Kun Prasetya, and Muhsinatun Siasah Masruri, "Model Pendidikan Karakter Terintegrasi Dalam Pembelajaran Dan Pengembangan Kultur Sekolah," Yogyakarta: Multi Presindo, 2013.

${ }^{25}$ Masnur Muslich and Pendidikan Karakter, "Menjawab Tantangan Krisis Multidimensional, Cet. 2," Jakarta: Bumi Aksara, 2011.
} 
sekolah yang sampai saat ini masih mengaktualisasikan pendidikan karakter, yaitu Sekolah Muhammadiyah Se-Kecamatan Juntinyuat Kabupaten Indramayu. Alasan peneliti melakukan penelitian di sekolah ini adalah karena sekolah ini memiliki siswa-siswa yang memiliki karakter baik, berprestasi dalam bidang ekstrakurikuler, menjunjung tinggi nilai-nilai ajaran agama dan pernah menjadi percontohan Kurikulum 2013.

Penelitian lain yang telah dilakukan oleh Endrise Septiana Rawanoko ${ }^{26}$ yang berjudul Implementasi Pendidikan Karakter Demokrasi melalui Pembelajaran PKN pada Siswa Kelas XII di SMA. Penelitian ini lebih terfokus pada implementasi nilainilai karakter demokrasi dalam pembelajaran PKN dan hanya terfokus pada satu kelas yaitu XII. Namun, penelitian ini menurut peneliti tidak mencakup semua nilainilai karakter yang lain dan terlalu spesifik. Penelitian tersebut kurang analisis dari segi temuan dan kesimpulanya, selain itu tidak dijelaskan nilai-nilai karakter apa yang difasilitasi oleh sekolah untuk diimplementasikan dan nilai-nilai apa yang telah terimplementasi dengan baik. Oleh karena itu, dibalik kekurangan tersebut peneliti akan mencoba mengaji lebih dalam lagi bagaimana implementasi pendidikan karakter dalam pembelajaran PAI serta nilai-nilai karakter apasaja yang diprogram untuk difasilitasi dan nilai-nilai apa yang telah teraktualisai dengan baik.

Penelitian yang akan dilaksanakan di Sekolah Muhammadiyah se-Kecamatan Juntinyuat Kabupaten Indramayu yang terdiri dari MI, SMP, dan SMK karena sekolah tersebut merupakan sekolah percontohan yang menerapkan Kurikulum 2013, dan memiliki keunggulan dalam beberapa kegiatan ekstrakurikuler. Permasalahan yang terjadi di sekolah-sekolah tersebut adalah beban Kurikulum 2013 mengharuskan siswa menyelesaikan banyak pekerjaan rumah sehingga ketika sampai di sekolah motivasi belajar turun. Di sisi lain studi pendahuluan yang dilakukan di Sekolah-Sekolah Muhammadiyah Se-Kecamatan Juntinyuat Kabupaten Indramayu menunjukan bahwa pelaksanaan pendidikan karakter masih belum optimal dilakukan baik dari segi perencanaan, proses maupun evalusinya. Dalam melaksanakan pembelajaran Pendidikan Agama Islam (PAI) dengan Kurikulum 2013, guru belum mengoptimalkan pendekatan saintifik yang meliputi mengamati, menanya, mengumpulkan data, mengasosiasi dan mengomunikasikan. Hal ini terlihat dalam kegiatan pembelajaran dengan metode ceramah dan diskusi, guru menjelaskan materi pembelajaran kemudian menugaskan siswa untuk berkelompok mengerjakan soal. Setelah mengerjakan soal yang sesuai dengan materi yang telah dijelaskan siswa ditugaskan untuk mempresentasikan hasil. Pada saat presentasi ada siswa yang mendominasi tetapi ada juga siswa yang kurang termotivasi dalam pembelajaran. Kegiatan selanjutnya adalah memberikan kesempatan kepada siswa kelompok lain untuk mempresentasikan hasil. Proses pembelajaran tersebut menyebabkan tidak semua siswa dapat mengonstruk kompetensi pengetahuan, sikap (yang termasuk ranah afektif termasuk: nilai, motivasi, kesadaran diri dll) dan keterampilannya.

\footnotetext{
${ }^{26}$ Endrise Septine Rawanoko and Wuri Wuryandani, "Implementasi Pendidikan Karakter Demokratis Melalui Pembelajaran Ppkn Pada Siswa Kelas XII," Harmoni Sosial: Jurnal Pendidikan IPS 4, no. 2 (2017): 187-96.
} 
Selain itu, Berbagai upaya yang telah dilakukan oleh pendidik, tenaga kependidikan, dan pengemban kebijakan pendidikan. Usaha tersebut tidak hanya pada aspek kognitif, tetapi aspek afektif dan psikomotorik juga harus diseimbangkan karena ketiganya akan memberikan pengaruh besar terhadap keberhasilan pendidikan karakter. Upaya yang dilakukan termasuk mencari solusi dan jalan keluar untuk meminimalisir karakter siswa dan kultur sekolah yang bersifat negatif. Dengan mengetahui pengaruh ketiga faktor, yaitu pendidikan karakter, kultur sekoah, dan pembelajaran PAI, maka dapat diupayakan solusi dan penyelesaian untuk meminimalisir karakter siswa yang bersifat negatif sehingga tidak ada hambatan lagi untuk mewujudkan tujuan pendidikan nasional.

\section{Metode Penelitian}

\section{Jenis Penelitian}

Penelitian ini menggunakan kualitatif dengan jenis studi kasus. Studi kasus adalah salah satu jenis pendekatan kualitatif yang penelitianya mengeksplorasi kehidupan nyata, sistem terbatas kontemporer (kasus) atau beragam sistem terbats (berbagai kasus), melalui pengumpulan data yang detail dan mendalam yang melibatkan beragam sumber informasi dan melaporkan deskripsi kasus dan tema kasus terhadap berbagai berbagai peristiwa-peristiwa dan aktivitas yang terjadi di Sekolah Muhammadiyah Se-Kecamatan Juntinyuat Kabupaten Indramayu yang meliputi ${ }^{27}$. Pendekatan dalam penelitian ini adalah naturalistik artinya peneliti tidak berusaha memanipulasi latar penelitian, tetapi melakukan studi terhadap suatu fenomena/peristiwa. Fokus penelitian dapat berupa orang, kelompok, program, pola hubungan, ataupun interaksi semuanya itu dilihat dalam konteks alamiah. Dengan demikian, peneliti melalui pengalaman peneliti berusaha mengkonstruksi pandangan tentang dunia sekitar ${ }^{28}$.

\section{Unit Analisis}

Unit analisis dalam penelitian ini adalah (1) perencanaan pendidikan karakter dalam pembelajaran PAI; (2) pelaksanaan pendidikan karakter dalam pembelajaran PAI; dan (3) penilaian pendidikan karakter dalam pembelajaran PAI.

\section{Sumber Data}

Sumber data dalam penelitian kualitatif dapat digolongkan menjadi dua yaitu sumber data primer dan sumber data sekunder. Sumber data primer dalam penelitian ini adalah data yang diperoleh langsung dari subyek penelitian tentang Aktualisasi Pendidikan Karakter dalam Pembelajaran PAI di Sekolah Muhammadiyah Se-Kecamatan Juntinyuat Kabupaten Indramayu. Sedangkan sumber data sekunder adalah sumber data tambahan yang berupa dokumen dan bahan kepustakaan yang dianggap relevan dengan penelitian.

\footnotetext{
${ }^{27}$ John W Creswell, "Penelitian Kualitatif \& Desain Riset Memilih Diantara Lima Pendekatan," Yogyakarta: Pustaka Pelajar, 2015.

${ }^{28}$ M Djunaidi Ghony and Fauzan Almanshur, “Metodologi Penelitian Kualitatif," Jogjakarta: Ar-Ruzz Media, 2012.
} 


\section{Teknik dan Instrumen Pengumpulan Data}

Dalam konteks penelitian kualitatif, pengumpulan data sering dilakukan dengan melihat kondisi alamiah (natural setting), sumber data primer, dan teknik pengumpulan data lebih banyak pada observasi berperan serta (particifan observation), wawancara mendalam (in depth interview) dan dokumentasi ${ }^{29}$. Oleh karena itu, dalam penelitian ini instrumen pengumpul data yang utama adalah (key instrument) yaitu peneliti sendiri. Adapun teknik pengumpulan data yang digunakan dalam penelitian ini adalah:

1. Observasi, dalam hal ini, peneliti terjun langsung ke lokasi penelitian dan ikut berpartisipasi sebagai asisten pembina ekstrakurikuler dalam kegiatan yang terjadi di lingkungan sekolah sambil melakukan pengamatan. Akan tetapi pada saat ada kegiatan yang dilakukan oleh siswa peneliti memberhentikan pengamatan karena berbagai pertimbangan yang menimbulkan dampak seperti mengganggu kegiatan tersebut, sehingga peneliti mengamati dari kejauhan. Observasi dilaksanakan di Sekolah Muhammadiyah Se-Kecamatan Juntinyuata Kabupaten Indramayu, adapun subjek yang diobservasi antara lain; (a) kegiatan di dalam kelas, seperti proses belajar mengajar, diskusi kelompok. (b) Kegiatan di luar kelas, seperti kegiatan ekstra kulikuler, kegiatan peringatan hari besar islam (PHBI) dan kegiatan guru serta kepala sekolah pada saat berada di luar kelas.

2. Wawancara, dalam penelitian ini bentuk wawancara terhadap informan dengan menggunakan pedoman wawancara yaitu membuat catatan tentang pokokpokok pertanyaan yang sesuai dengan tujuan penelitian. Berangkat dari pendapat tersebut, peneliti melakukan wawancara dengan dua cara; yaitu wawancara terstruktur, dengan wawancara tidak terstruktur yang ditujukan kepala sekolah, wakil kepala sekolah bidang kesiswaan, guru BK, guru PKN, guru PAI, dan siswa mengenai proses aktualisasi pendidikan karakter berbasis kultur sekolah dalam pembelajaran PAI di Sekolah Muhammadiyah Se-Kecamatan Juntinyuat Kabupaten Indramayu. Berikut akan dijelaskan tabel mengenai kisikisi wawancara yang digunakan dalam penelitian ini:

3. Dokumentasi dalam penelitian ini adalah suatu proses pengambilan beberapa dokumen yang dijadikan sebagai bukti rasional dan empirik yang terkait dengan tujuan penelitian. Pada tahap ini, peneliti meminta profil sekolah Sekolah Muhammadiyah Se-Kecamatan Juntinyuat sebagai langkah awal untuk melihat kondisi sekolah tersebut.

\section{Teknik Analisis Data}

Menurut Bogdan \& Bike analisis data adalah upaya yang dilakukan dengan bekerja dengan data, mengorganisasi data, memilah-milahnya menjadi satuan data yang dapat dikelola, mensintesiskan data, mencari dan menemukan pola,

\footnotetext{
${ }^{29}$ Sugiyono, Metode Penelitian Pendidikan:(Pendekatan Kuantitatif, Kualitatif Dan R \& D) (Alfabeta, 2008).
} 


\section{Ali Miftakhu Rosyad}

Implementasi Pendidikan Karakter dalam......

menemukan apa yan penting dan apa yang dipelajari, dan memutuskan apa yang dapat diceritakan kepada orang lain ${ }^{30}$.

Dalam penelitian ini digunakan teknik analisis model interaktif yaitu dengan menggunakan langkah-langkah sebagai berikut.

1. Pengumpulan data

Data dikumpulkan dengan tujuan untuk memperoleh atau mendapat informasi di lapangan sesuai dengan kebutuhan peneliti dan rumusan masalah sehingga memungkinkan data tersebut harus akurat.

2. Reduksi data

Data yang diperoleh di lapangan semakin bertambah banyak, sehingga perlu dilakukan reduksi, dirangkung, dipilih, diberi kode dan diambil yang penting dari tema dan polanya. Melalui proses reduksi data laporan mentah di lapangan menjadi lebih sistemati sehingga mudah dikendalikan.

\section{Penyajian data}

Setelah data direduksi maka, langkah berikutnya adalah menyajikan data. Dalam penelitian ini, penyajian data dilakukan dalam bentuk uraian teks yang bersifat deskriptif yang mengungkapkan tentang aktualisasi pendidikan karakter berbasis kultur sekolah dalam pembelajaran PAI pada empat dimensi yaitu perencanaan pendidikan karakter berbasis kultur sekolah, pelaksanaan pendidikan karakter berbasis kultur sekolah, penilaian pendidikan karakter berbasis kultur sekolah, dan peran kultur sekolah dalam pendidikan karakter. Selain itu, menyajikan data yang berhubungan dengan dukungan komite sekolah, orang tua, dan masyarakat melalui kultur sekolah serta aktualisasi pendidikan karakter malalui kultur sekolah meliputi kegiatan rutinitas, kegiatan spontanitas, keteladanan, dan pengkondisian lingkungan.

\section{Pengambilan Simpulan}

Pengambilan simpulan dilakukan untuk menyederhanakan data dan informasi yang diperoleh guna mencapai pola, tema, hubungan, persamaan, dan hal-hal lain yang sering timbul. Pengambilan simpulan ini diklarifikasi dan diverifikasi selama penelitian berlangsung.

30 J Moleong, “Lexy. 2014, Metodologi Penelitian Kualitatif, Bandung: PT," Remaja Rosdakarya, n.d. 


\section{Hasil Penelitian dan Pembahasan}

\section{Perencanaan pendidikan karakter dalam pembelajaran PAI}

Pada praktek implementasi pendidikan karakter, pengembangan RPP harus terlebih dahulu dipahami arti dan tujuan pembelajaran, serta dikuasai secara teoretis dan praktis unsur-unsur yang terdapat di dalamnya. Kemampuan membuat RPP merupakah langkah awal yang harus dimiliki oleh setiap guru dalam aktualisasi pendidikan karakter di sekolah, dan sebagai muara dari segala pengetahuan teori, ketrampilan dasar, dan pemahaman yang mendalam tentang objek dan situasi pembelajaran. Dalam RPP harus jelas karakte dan kompetensi dasar yang akan dimiliki oleh siswa ${ }^{31}$.

Berdasarkan hasil temuan di lapangan melalui wawancara, observasi, dan analisis dokumentasi menunjukan bahwa dalam kegiatan perencanaan pendidikan karakter melalui proses pembelajaran ada beberapa nilai-nilai karakter yang dikembangkan melalui proses pembelajaran yang termuat dalam RPP, Silabus, dan program sekolah, tabel dibawah ini akan menjelaskan sejumlah nilai-nilai karakter yang akan dikembagkan

Tabel 1. Nilai-Nilai Karakter yang Dikembangkan dalam KBM

\begin{tabular}{|c|c|c|}
\hline No & Nilai Karakter & Deskripsi \\
\hline 1 & Kedisiplinan & $\begin{array}{l}\text { Siswa memiliki antusias dan minat yang tinggi dalam kegiatan } \\
\text { ekstrakurikuler dan memiliki prestasi yang baik diberbagai perlombaan. } \\
\text { Namun kasus negatif terbanyak yaitu tidak mengerjakan PR dan datang } \\
\text { terlambat ke sekolah. }\end{array}$ \\
\hline 2 & Kejujuran & $\begin{array}{l}\text { Kasus negatif terbanyak adalah mencontek pada saat latihan dan ulangan } \\
\text { harian. }\end{array}$ \\
\hline 3 & Kerja Sama & $\begin{array}{l}\text { Kasus positif yang terjadi dalam hal ini adalah saling menjenguk ketika ada } \\
\text { teman yg sakit dan kemauan siswa untuk saling menolong di lingkungan } \\
\text { sekolah. Namun kasus negatif yang sering terjadi adalah berkelahi. }\end{array}$ \\
\hline 4 & $\begin{array}{l}\text { Tanggung } \\
\text { Jawab }\end{array}$ & $\begin{array}{l}\text { Dalam pendidikan karakter ini siswa dibimbing untuk bertanggung jawab } \\
\text { secara sadar. Seperti siswa diberi tugas dan pekerjaan rumah, selain itu ketika } \\
\text { siswa terlambat dan melanggar tata tertib mereka juga dilatih untuk } \\
\text { tanggung jawab menerima sanksi akibat perbuatanya. }\end{array}$ \\
\hline 5 & Demokrasi & $\begin{array}{l}\text { Perilaku positif dalam hal ini terutama dalam kegiatan belajar-mengajar } \\
\text { adalah siswa dilatih untuk menghargai pendapat temanya yang berbeda } \\
\text { pemikiran dan terbuka menerima masukan orang lain. }\end{array}$ \\
\hline 6 & Peduli Sosial & $\begin{array}{l}\text { Sikap dan tindakan ini berupa keinginan untuk saling membantu sesama } \\
\text { temanya baik di dalam kelas dan di luar kelas. }\end{array}$ \\
\hline 7 & Rasa Hormat & $\begin{array}{l}\text { di lingkungan sekolah baik dalam kelas dan diluar kelas siswa dilatih untuk } \\
\text { bersikap hormat kepada temanya sesama siswa, pendidik, tenaga } \\
\text { kependidikan, tamu dan lain sebagainya }\end{array}$ \\
\hline 8 & Religius & $\begin{array}{l}\text { Perilaku positif dalam hal ini adalah siswa memiliki kepatuhan untuk sholat } \\
\text { berjamaah dan mengikuti kegiatan bimbingan membaca Alquran. Kasus } \\
\text { negatif yang sering terjadi adalah peserta didik yang membolos untuk } \\
\text { mengikuti sholat berjamaah dan bimbingan membaca Alquran. }\end{array}$ \\
\hline
\end{tabular}

Sumber: Kurikulum Sekolah Muhammadiyah, 2019

${ }^{31}$ Mulyasa, "Manajemen Pendidikan Karakter, Cet." 
Perencanaan pengembangan kultur sekolah di Sekolah Muhammadiyah SeJuntinyuat Kabupaten Indramayu dalam konteks perencanaan pembelaj-aran sering kali berkaitan penyusunan rencana pelaksanaan pembelajaran (RPP) dan admninistr-asi lainya merupakan suatu perkiraan atau proyeksi guru mengenai seluruh kegiatan baik itu oleh guru maupun peserta didik, terutama dalam pembentukan karakter. Perencanaan pembelajar-an seharusnya mendukung perencanaan pengem-bangan kultur sekolah baik dimensi fisik, nilai, dan pesan verbal. Selama peneliti melaksanakan observasi di lapangan dapat ditemukan semua guru telah mimiliki perangkat RPP dan administrasi lainya. Di dalamnya terdapat tujuan pembelajaran metode, sumber belajar, dan rencana penilaian pembelajaran.

Berdasarkan realita yang terjadi menunjuk-an bahwa keberadaan perencanaan pengembangan kultur sekolah sangat diperlukan untuk menghadapi berbagai perubahan yang terjadi lingkungan sekolah, media masa, dan masyarakat. Perencanaan pengembangan kultur sekolah di Sekolah Muhammadiyah SeJuntinyuat juga perlu didukung oleh kegiatan pembelajaran dan perencanaan pembelajaran. Penyusunan adminis-trasi pembelajaran terutama Rencana Pelaksanaan Pembelajaran (RPP) yang dibuat oleh guru harus memuat komponen inti pada pendidikan. Komponen inti pada pendidikan yaitu kurikulum, proses pembelajaran dan penilaian. Pendidikan karakter akan berlangsung lebih baik kalau kegiatan pembelajaran membantu untuk mewujudkan visi, misi, dan program sekolah.

Pelajaran PAI mempersiapkan siswa untuk mengidentifikasi, memahami, dan bekerja untuk memecahkan tantangan yang dihapadi bangsa ini yang beragam di dunia yang semakin saling ketergantungan. Pendidikan Agama Islam harus membantu siswa memperoleh dan belajar untuk mengemba-ngkan ketrampilan, pengetahuan, dan sikap yang akan mempersiapkan mereka untuk menjadi warga negara yang kompeten, bertangg-ung jawab, bijaksana, dan berpartisipasi dalam komunitas mereka, terlibat secara politik, dan menunjukan kebijakan moral dan sipil yang berkeadilan. Kurikulum yang mendukung pendidikan karakter akan berjalan sesuai dengan konsep yang akan dicapai. Pada proses pembelajaran guru akan menitik beratkan pendidikan karakter agar pencapaian nilai pada akhir pembelajaran memenuhi kriteria yang telah ditentukan.

Pengintegrasian pendidikan karakter pada RPP yang dilakukan oleh guru PAI terlihat pada penentuan nilai-nilai karakter yang akan dikembangkan dalam kegiatan belajar mengajar. Lebih detail lagi Gunawan ${ }^{32}$ pengembangan pendidikan karakter yang diintegrasikan dalam proses pembelajaran dilaksanakan mulaia dari tahap perencanaan, pelaksanaan, dan evaluasi pembelajaran pada semua mata pelajaran. Di antara prinsip-prinsip yang dapat diadopsi dalam membuat perencanaan pembelajaran (merancang kegiatan pembelajaran dan penilaian dalam silabus, RPP, dan bahan ajar), melaksanakan proses pembelajaran, dan evaluasi adalah prinsip-prinsip pembelajaran kontekstual yang selama ini telah

${ }^{32}$ Gunawan Heri, “Pendidikan Karakter Konsep Dan Implementasi,” Bandung: Alfabeta, 2012. 
diperkenalkan kepada guru. Pada tahap ini silabus, RPP, dan bahan ajar dirancang agar muatan maupun kegiatan pembelajaranya memfasilitasi/berwawa-an pendidikan karakter.

Aktualisasi pendidikan karakter yang diintegrasikan dalam perencanaan pengembangan kultur sekolah melalui pembelajaran tercantum pada RPP, yaitu mengkaji kompetensi inti dan kompetensi dasar agar dapat menyesuaikan nilai-nilai budaya dan karakter bangsa yang dimuat di dalamnya. Nilai-nilai karakter yang akan dikembangkan dalam perencanaan adalah disiplin, demokrasi, religius, kerja sama, peduli sosial, rasa hormat, jujur, dan tanggung jawab Agar proses pengembangan pembelajaran peserta didik berjalan secara aktif maka guru dapat memberikan bantuan pada peserta didik yang mengalami kesulitan dalam menginternalisasi nilainilai karakter.

\section{Pelaksanaan pendidikan karakter dalam pembelajaran PAI}

Pelaksanaan pengembangan kultur sekolah di Sekolah Muhammadiyah SeKecamatan Juntinyuat Kabupaten Indramayu dilaksanakan secara bersama-sama oleh kepala sekolah, pendidik, tenaga kependidikan, dan siswa di Sekolah Muhammadiyah Se-Kecamatan Juntinyuat Kabupaten Indramayu baik kegiatan yang dirancang sekolah secara umum dan kegiatan lainya yang berasal dari ide guru dan siswa. Dalam hal ini pelaksanaan pembelajaran IPS yang di ampuh oleh guru harus lebih mendukung sebaik mungkin pengembangan kultur sekolah melalui kegiatan pembelajaran.

Proses pembelajaran adalah interaksi yang dilakukan antara guru dengan siswa untuk mewujudkan tujuan yang ditetapkan. Proses pembelajaran akan berjalan secara efektif dan efisien apabila guru mampu menciptakan ruang kelas yang kondusif dan demokratis. Iklim belajar dalam kelas yang kondusif dapat memberikan gambaran positif melalui pembelaja-jaran yang dilakukan sehari-hari, selain itu siswa juga dapat belajar nilai-nilai karakter melalui perbedaan yang ada dikelas. Akan tetapi iklim kelas yang kurang menyenangkan akan menimbulkan kejenuhan dan rasa bosan ${ }^{33}$.

Guru PAI harus menyadari bahwa siswa tidak menjadi tanggung jawab dan berpartisipasi sebagai peserta didik dalam proses pembelajaran secara otomatis. Nilai-nilai yang terkandung dalam bentuk demokrasi diperintahkan kita, dengan komitmen keadilan, kesetaraan dan kebe-basan berpikir dan berbicara tercermin dalam praktik pembelajaran PAI di kelas. Disinilah peran guru PAI dalam mengembangkan nilai-nilai pendidikan karakter.

Pada pelaksanaan pembelajaran di Sekolah Muhammadiyah Se-Kecamatan Juntinyuat Kabupaten Indramayu metode pembelajaran yang digunakan oleh guru PAI adalah metode yang komprehensif yang meliputi inquiry, problem based

\footnotetext{
${ }^{33}$ Abdul Majid, "Perencanaan Pembelajaran Mengembangkan Kompetensi Guru," PT Remaja Rosdakarya. Bandung, 2011.
} 
learning, problem solving, diskusi, dan lain-lain. Dengan metode inquiry diharapkan dapat mengembangkan karakter demokrasi, rasa ingin tahu, dan rasa hormat pada siswa. Dengan metode problem based learning bertujuan untuk mengembangkan sikap kerja sama, peduli sosial, disiplin, dan tanggung jawab pada siswa. Dengan metode problem solving bertujuan untuk mengembangkan sikap peduli sosial, jujur, dan tanggung jawab pada siswa. Dengan metode diskusi bertujuan untuk mengembangkan sikap rasa ingin tahu, disiplin, tanggung jawab, dan peduli sosial pada siswa.

Pada dasarnya proses pembelajaran tidak akan berjalan dengan baik apabila guru tidak terampil dalam menggunakan metode yang tepat. Dalam pendidikan karakter muncul kesadaran akan perlunya implementasi pendekatan yang komprehensif yang diharapkan dapat menghasil-kan lulusan yang mampu membuat keputusan moral dan sekaligus memiliki perilaku yang terpuji berkat pembiasaan terusmenerus dalam proses pembelajaran. Dari segi metode pendekat-an yang komprehensif meliputi: inkulkasi (inculcation), keteladanan (modeling), fasilitas (facilitation), dan pengembangan ketrampilan (skill building) (Zuchdi, 2009).

Setelah peneliti melakukan observasi dan wawancara mengenai aktualisasi pendidikan karakter dalam pembelajaran PAI di Sekolah Muhammadiyah SeKecamatan tidak hanya metode saja yang berpengaruh dalam menumbuhkan nilainilai karakter, namun guru adalah komponen terpenting. Guru dituntut untuk dapat melakukan tiga hal yaitu: 1) kemampuan membuka dan menutup pelajaran, 2) kemampuan menjelaskan materi pelajaran, 3) kemampuan memotivasi peserta didik untuk berani bertanya. Berikut ini akan dijelaskan gambar skema pelaksanaan aktualisasi pendidikan karakter yang terintegrasi dalam pembelajaran PAI sebagai berikut $^{34}$.

Pelaksanaan pengembangan kultur sekolah di Sekolah Muhammadiyah SeKecamatan Juntinyuat Kabupaten Indramayu dalam pembelajaran PAI berdasarkan RPP yang dibuat oleh guru dalam kegiatan inti pembelajaran menggunakan metode yang komprehensif. Proses pembelajaran PAI yang dilakukan dengan metode komprehensif di kelas akan mampu memunculkan nilai-nilai karakter siswa sehingga peserta didik dapat berdisiplin, tanggung jawab, peduli sosial, demokrasi, kerja sama dan selain itu memunculkan partisipasi aktif dalam berpendapat. Sebagaimana dikutip oleh Lickona dalam Samani dan Haryanto (2011) mengemukakan bahwa agar pendidikan karakter berjalan efektif dan efisien guru harus kreatif dalam memilih metode yang sesuai dalam pendidikan karakter. Implementasi berbagai metode seperti bercerita tentang berbagai kisah, cerita atau dongeng yang sesuai, menugasi siswa membaca literatur, melaksanakan studi kasus, bermain peran, diskusi, debat tentang moral dan juga penerapan pembelajaran kooperatif. Dalam artian dengan metode diatas siswa dalam pembelajaran akan dihadapkan pada pertnyaan dan pernyataan yang bersifat problematis dan aktual untuk dipecahkan dalam kelas.

\footnotetext{
${ }^{34}$ Darmiyati Zuchdi, “Humanisasi Pendidikan,(Jakarta: PT,” Bumi Aksara, 2008.
} 
Melihat situasi dan kondisi sekarang agar siswa dapat memahami lingkungan sosial dan berpartisipasi aktif didalamnya maka tujuan pendidikan PAI adalah membina peserta didik menjadi warga negara yang baik yang memiliki pengetahuan, keterampilan, dan kepedulian sosial yang berguna bagi dirinya sendiri, masyarakat dan bangsa. Untuk merealisasikan itu semuanya maka, kegiatan belajar mengajar tidak terpbatas pada aspek kognitif dan psikomotorik saja, melainkan meliputi aspek akhlak (afektif) agar siswa dapat menyadari bahwa kehidupan sekarang penuh masalah, tantangan, hambatan, dan persaingan (Rachmah, 2014). untuk menumbuhkan karakter yang baik maka diperlu-kan juga suatu usaha untuk mengembang-kan kompetensi afektif, kognitif, dan psikomotor-ik secara berkesinambungan

Selain itu menurut penjelasan Daryanto \& Darmiyatun ${ }^{35}$ bahwa implem-entasi pendidikan karakter pada konteks mikro berpusat pada satuan pendidikan formal dan nonformal secara holistik. Dalam hal ini pengembangan nilai-nilai karakter dibagi menjadi empat yaitu kegiatan belajar mengajar di kelas, kegiatan keseharian dalam bentuk pengembangan budaya satuan pendidikan formal, kegiatan kokurikuler dan/atau ekstakurikuler, serta kegiatan keseharian di rumah dam masyarakat. Dalam kegiatan belajar mengajar di kelas, pelaksanaan pendidik-an karakter berbasis kultur sekolah dapat terintegrasi melalui KBM di kelas.

Setelah peneliti melakukan wawancara mendalam dan observasi dengan warga sekolah dapat disimpulkan bahwa aktualisasi nilai-nilai karakter yang baik dan kultur sekolah yang positif tidak akan terwujud dengan maksimal kalau hanya didasark-an pada peraturan, kode etik, dan tata tertib yang ketat serta mengikat, tetapi kultur sekolah yang positif dan aktualisasi nilai-nilai karakter yang baik akan terwujud kalau didasarkan dengan kesadaran tiap warga sekolah.

Aktualisasi pendidikan karakter di Sekolah Muhammadiyah Se-Kecamatan Juntinyuat Kabupaten Indramayu harus diupayakan lebih sistematis, berkesinambungan dan tiada henti untuk membentuk moral knowing, moral feeling dan moral action pada siswa maka diperlukan strategi dan pendekatan yang komprehensif. Tiga kompetensi diatas harus dikuasai oleh siswa agar mampu mewujudkan standar kompetensi lulusan yang berakhlak mulia dan mampu menjadi warga negara yang demokratis dan bertanggung jawab sesuai dengan tujuan pembelajaran IPS.ketiga kompetensi itu harus diusahakan dalam kegiatan pembelajaran di kelas.

Pernyataan tersebut diperkuat oleh teori Lickona ${ }^{36}$ menambahkan kompo-nen kelas dalam aktualisasi pendidikan karakter, Clasroom components are;(1) the teacher as caregiver, moral, model, and moral mentor; (2) creating and caring classroom community; (3) moral discipline; (4) creating a democratic classroom

\footnotetext{
${ }^{35}$ Daryanto, "Implementasi Pendidikan Karakter Di Sekolah."

${ }^{36}$ Thomas Lickona, "The Teacher's Role in Character Education," Journal of Education, 1997, https://doi.org/10.1177/002205749717900206.
} 
envoronment; (5) teaching values through curriculum; (6) cooperative learning; (7) the conscience of craft; (8) ethical reflection; and (9) teaching conflict resolution.

Aktualisasi pendidikan karakter dapat dilakukan dengan berbagai strategi pengintegras-ian berdasarkan wawancara dengan 3 orang guru mata pelajaran PAI pada 15 July 2019 bahwa mereka menggunakaan metode komprehensif yang meliputi inquiry, diskusi, problem based learning, bermain peran, problem solving untuk membiasakan dan melatih nilai-nilai karakter pada siswa terutama dalam proses pembelajaran di dalam kelas

Aktualisasi pendidikan karakter yang dilakukan oleh guru PAI di Sekolah Muhammadiyah Se-Kecamatan Juntinyuat adalah menumbuhkan nilai-nilai karakter mulia dan akhlak terpuji melalui pembelajaran. Agar mereka memiliki kepedulian sosial dan sadar akan tanggung jawabnya sebagai warga negara yang demokratis. Aktualisasi pendidikan karakter tidak hanya diterapkan dalam pembelajaran saja, namun dapat di integrasikan kedalam budaya sekolah. Setelah peneliti melakukan observasi partisipant dapat dilihat bahwa pengintegrasian kultur sekolah di Sekolah Muhammadiyah Se-Kecamatan Juntinyuat Kabupaten Indramayu dapat dilihat melalui kegiatan yang ada di sekolah, kegiatan ekstrakurikuler, dan kegiatan lain yang diikuti baik oleh seluruh atau sebagian siswa. Adapun ekstrakurikuler yng diikuti oleh siswa-siswi Sekolah Muhammadiyah Se-Kecamatan Juntinyuat Kabupaten Indramayu adalah Paskibra, PMR (Palang Merah Remaja) Pramuka, Sepak Bola, Bola Basket, dan Paduan suara. Ekstrakurikuler yang ada disekolah diharapkan mampu mewadahi dan mengembang-kan minat dan bakat siswa, selain itu dengan adanya berbagai macam kegiatan ekstrakurikuler adalah perwujudan dari sekolah yang berdemokratis dan memfasilitasi siswa untuk memilih dalam berpartisipasi aktif. Sesuai dengan teori Gunawan (2012) menyatakan bahwa

"Pengintegrasian pendidikan karakter melalui kultur sekolah dapat dilakukan dengan cara: (1) penugasan; (2) pembiasaan; (3) pelatihan; (4) pengajaran; (5) pengarahan; dan (6) keteladanan, yang dapat dilakukan melalui intra kurikuler, ekstrakurikuler, peringatan hari besar islam dan kegiatan lainya yang menunjang dalam pengemb-angan karakter peserta didik".

Aktualisasi pendidikan karakter akan berjalan lebih optimal apabila diterapkan melalui pembelajaran di kelas dan diluar kelas atau kultur sekolah. Aktualisasi pendidikan karakter yang diterapkan di dalam kelas dapat diintegrasikan dalam pembelajaran PAI. Sedangkan aktualisasi pendidikan karakter yang dterapkan melalui kultur sekolah bisa diimplementasikan melaui ekstrakurikuler, peringatan hari besar islam, dan lain sebagainya. 


\section{Evaluasi pendidikan karakter dalam pembelajaran PAI}

Evaluasi adalah langkah penting yang dilakukan sekolah untuk mengidentifikasi kebe-rhasilan dan tindak lanjut dalam aktualisasi pendidikan karakter melalui kultur sekolah. Evaluasi merupakan bagian yang tak terpisahk-an dari aktualisasi pendidikan karakter berbasis kultur sekolah karena dengan evaluasi dapat diketahui faktor penghambat,faktor pendukung dan bagaimana hubungan aktualisasi nilai-nilai karakter dengan kultur sekolah.

Evaluasi adalah suatu proses penilaian untuk mengambil keputusan yang menggunak-an seperangkat hasil pengukuran dan berpedo-man kepada tujuan yang telah ditetapkan. Evaluasi disini merupakan perpaduan dari penilaian dan pengukuran. ${ }^{37}$

Dalam aktualisasi pendidikan karakter di lingkungan sekolah diperlukan langkah akhir yaitu penilaian yang harus dilakukan secara terus menerus dan berkesinambungan, untuk mengetahui dan memantau perubahan serta kemajuan siswa, maupun memberi skor atau nilai yang biasa dikonversi melalui penilaian hasil belajar ${ }^{38}$.

Pernyataan tersebut sesuai pendapat Arifin $^{39}$ membagi model-model evaluasi ada 9 yaitu; 1.) model tyler; 2.) model yang berorentasi pada tujuan; 3.) model pengukuran; 4.) model kesesuaian; 5.) educatio-nal system evaluation model; 6.) model alkin; 7.) illuminative model; 8.) Model Brinkerhoff; dan 9.) model responsif. Untuk pengukuran sikap model evaluasi yang digunakaan yaitu model pengukuran. Model pegukuran menitikb-eratkan pada kegiatan pengukuran yang diguna-kan untuk menentukan kuantitas suatu sifat tertentu yang telah dimiliki oleh objek, orang maupun peristiwa, dalam bentuk unit maupun ukuran tertentu. Dalam dunia pendidikan di sekolah, model ini diterapkan untuk menentuk-an perbedaan-perbedaan individual maupun kelompok dalam hal kompetensi, minat, dan sikap. Objek evaluasi dalam model ini adalah tingkah laku peserta didik mencakup hasil belajar (kognitif), pembawaan, sikap, minta, bakat, dan juga aspek-aspek kepribadian peserta didik. Model ini menggunakan pendekatan penilaian acuan norma (PAN) (norm-referenced assessment). Pada penilaian sikap maka objek evaluasi adalah peserta didik yang diamati adalah perilaku peserta didik yang mencakup hasil belajar, sikap dan pembawaan peserta didik.

Berdasarkan hasil temuan data di lapangan melalui wawancara, observasi, dan dokumentasi menunjukan bahwa evaluasi pendidikan karakter dalam pembelajaran IPS bertujuan untuk mengukur kompetensi sikap yang telah dikuasai siswa dengan menggunakan rubrik penilaian/catatan observasi dan tindak lanjut.

\footnotetext{
${ }^{37}$ Ismet Basuki and M S Hariyanto, “Asesmen Pembelajaran," Bandung, PT Remaja Rosda Karya, 2014.

${ }^{38}$ Enco Mulyasa, Pengembangan Dan Implementasi Kurikulum 2013 (PT Remaja Rosdakarya, 2013).

${ }^{39}$ Zainal Arifin, "Cetakan Ke 5: Evaluasi Pembelajaran Prinsip, Teknik, Prosedur," Bandung: Remaja Rosdakarya 61 (2013).
} 
Berikut ini akan dijelaskan gambar mengenai alur pelaksanaan evaluasi pendidikan karakter di SMP Negeri 2 Juntinyuat Kabupaten Indramayu sebagai berikut.

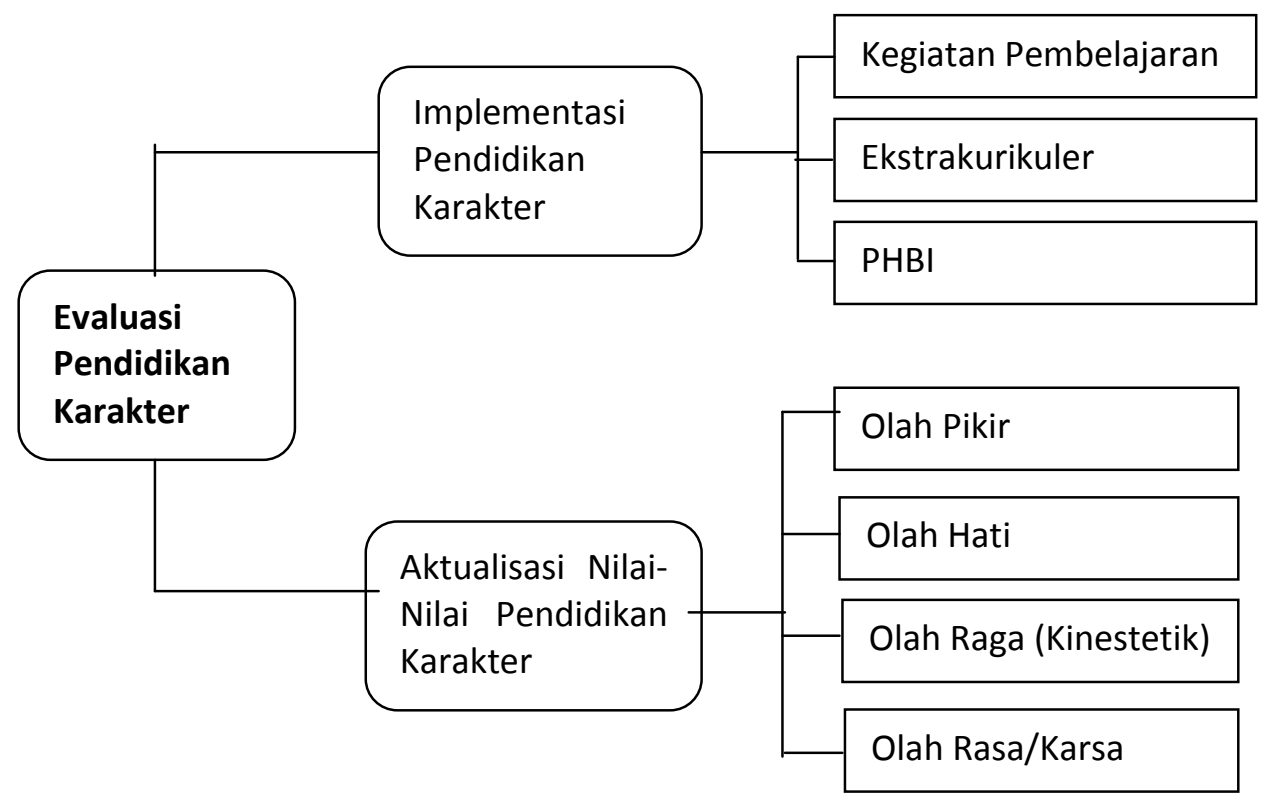

Gambar 3. Model Evaluasi Pendidikan Karakter

Penilaian kompetensi sikap yang dilak-an guru PAI di Sekolah Muhammadiyah Se-Kecamatan Juntinyuat Kabupaten Indramayu menggunakan rubrik penilaian/catatan observasi dan tindak lanjut. Rubrik penilaian/catatan observasi digunakan untuk menilai sikap seseorang. Ada tiga komponen sikap yaitu kognisi, afeksi, dan konasi $^{40}$. Kognisi berkaitan dengan pengetahuan atau kepercayaan seseorang mengenai objek atau stimulus yang dihadapinya, efeksi berkaitan dengan perasaan atau penilaian dalam menghadapi objek tersebut, sedangkan konasi berkaitan dengan kecendrungan untuk berperilaku atau berbuat dengan cara-cara tertentu terhadap objek tersebut dalam penilaian sekala sikap ini guru memiliki sebut journal yang dilampirkan beserta RPP.

Penilaian aktualisasi pendidikan karakter di Sekolah Muhammadiyah SeKecamatan Kabupaten Indramayu dilakukan dengan ${ }^{41}$ memanfaatkan rubrik penilaian atau catatan observasi guru PAI dan tidak lanjut. Penilaian kompetensi sikap dilakukan oleh guru PAI melalui bekerja sama dengan wali kelas dan guru BK supaya bisa diadakan evaluasi tindak lanjut. Catatan mengenai karakter siswa yang dimiliki oleh guru PAI disampaikan pada saat rapat guru dan kepala sekolah untuk mencari solusinya.

\footnotetext{
${ }^{40}$ Mimin Haryati, “Model Dan Teknik Penilaian Pada Tingkat Satuan Pendidikan” (Jakarta: Gaung Persada Press, 2007).

${ }^{41}$ Ali Miftakhu Rosyad and Darmiyati Zuchdi, "Aktualisasi Pendidikan Karakter Berbasis Kultur Sekolah Dalam Pembelajaran IPS Di SMP," Harmoni Sosial: Jurnal Pendidikan IPS, 2018, https://doi.org/10.21831/hsjpi.v5i1.14925.
} 
Penilaian pendidikan karakter setidaknya menyentuh tiga aspek sebagaimana dijelaskan oleh Lickona ${ }^{42}$ yang menyatakan bahwa

"Component of good characters is: (1) moral knowing (moral awarness, knowing moral values, perspective-taking, moral reasoning, decision-making, and self knowledge): (2) moral feeling (conscience, self esteem, emphaty, loving the good, self control, humanity); and (3) moral action (competence, will, and habit)"

Dapat dilihat bahwa aktualisasi pendidikan karakter dalam pembelajaran PAI pada siswa di Sekolah Muhammadiyah Se-Kecamatan Juntinyuat Kabupaten Indramayu dapat diimplementasikan siswa secara sistematis. Maka untuk pendidikan karakter dapat dievalusi dalam bentuk ulangan harian, rubrik penilaian /catatan observasi, dan tidak lanjut yang telah dirumuskan dalam RPP dan program sekolah untuk mengetahui perilaku siswa.

Berdasarkan hasil wawancara, observasi, dan dokumentasi dengan warga sekolah. Peneliti memperoleh kesimpulan bahwa ada 6 (enam nilai karakter yang telah teraktualisasi dengan baik yaitu nilai demokrasi, religius, kerja sama, peduli sosial, rasa hormat, dan tanggung jawab. Sebagaimana tabel dibawah ini.

Tabel 2. Nilai-Nilai Karakter yang Teraktualisasi dengan Baik

\begin{tabular}{|c|c|c|}
\hline No & Nilai Karakter & Deskripsi \\
\hline 1 & Kerja Sama & $\begin{array}{l}\text { Kasus positif yang terjadi dalam hal ini adalah saling menjenguk } \\
\text { ketika ada teman yg sakit dan kemauan siswa untuk saling } \\
\text { menolong di lingkungan sekolah. Namun kasus negatif yang sering } \\
\text { terjadi adalah berkelahi. }\end{array}$ \\
\hline 2 & Tanggung Jawab & $\begin{array}{l}\text { Dalam pendidikan karakter ini siswa dibimbing untuk bertanggung } \\
\text { jawab secara sadar. Seperti siswa diberi tugas dan pekerjaan rumah, } \\
\text { selain itu ketika siswa terlambat dan melanggar tata tertib mereka } \\
\text { juga dilatih untuk tanggung jawab menerima sanksi akibat } \\
\text { perbuatanya. }\end{array}$ \\
\hline 3 & Demokrasi & $\begin{array}{l}\text { Perilaku positif dalam hal ini terutama dalam kegiatan belajar- } \\
\text { mengajar adalah siswa dilatih untuk menghargai pendapat temanya } \\
\text { yang berbeda pemikiran dan terbuka menerima masukan orang } \\
\text { lain. }\end{array}$ \\
\hline 4 & Peduli Sosial & $\begin{array}{l}\text { Sikap dan tindakan ini berupa keinginan untuk saling membantu } \\
\text { sesama temanya baik di dalam kelas dan di luar kelas. }\end{array}$ \\
\hline 5 & Rasa Hormat & $\begin{array}{l}\text { di lingkungan sekolah baik dalam kelas dan diluar kelas siswa } \\
\text { dilatih untuk bersikap hormat kepada temanya sesama siswa, } \\
\text { pendidik, tenaga kependidikan, tamu dan lain sebagainya }\end{array}$ \\
\hline 6 & Religius & $\begin{array}{l}\text { Perilaku positif dalam hal ini adalah siswa memiliki kepatuhan } \\
\text { untuk sholat berjamaah dan mengikuti kegiatan bimbingan } \\
\text { membaca Alquran. Kasus negatif yang sering terjadi adalah peserta } \\
\text { didik yang membolos untuk mengikuti sholat berjamaah dan } \\
\text { bimbingan membaca Alquran. }\end{array}$ \\
\hline
\end{tabular}

Sumber: Kurikulum Sekolah Muhammadiyah, 2019

${ }^{42}$ Lickona, "The Teacher's Role in Character Education." 
Berdasarkan penjelasan tabel tersebut dapat disimpulkan bahwa nilai kedisiplinan dan kejujuran belum teraktualisasi dengan baik karena pengaruh negatif dari lingkungan sosial, media masa, dan penggunaan informasi dan teknologi yang tidak tepat. Nilai-nilai karakter yang sudah teraktualisasi dengan baik hendaknya dipertahankan, namun nilai-nilai karakter yang belum teraktualisasi dengan baik hendak dicari solusi dan tidak lanjutnya.

\section{Kesimpulan}

Berdasarkan hasil temuan dan pembahasan, maka perlu diambil kesimpulan sebagai berikut.

Pertama, perencanaan: pengembangan budaya Sekolah Muhammadiyah SeKecamatan Juntinyuat Kabupaten Indramayu memiliki rencana yang tertuang dalam program kerja sekolah. Guru PAI dalam proses perencanaan harus membantu untuk mewujudkan pengembangan kultur sekolah dalam kegiatan pembelajaran. Dalam RPP guru memasukkan nilai-nilai karakter mulia yang akan dikembangkan melalui kegiatan pembelajaran, yang meliputi nilai-nilai: disiplin, demokrasi, religius, kerja sama, peduli sosial, rasa hormat, jujur, dan tanggung jawab.

Kedua, pelaksanaan: aktualisasi pendidikan karakter dalam pembelajaran PAI berjalan baik, yang didukung oleh seluruh warga sekolah, komite sekolah, dan orang tua siswa. Pada proses belajar-mengajar guru menggunakan metode yang komprehensif, yang meliputi: ceramah bervariasi, diskusi, inquiri, tanya jawab, simulasi, observasi, problem solving, dan pembelajaran berbasis masalah. Aktualisasi pendidikan karakter di Sekolah Muhammadiyah Se-Kecamatan Juntinyuat Kabupaten Indramayu ditentukan oleh beberapa faktor, namun yang faktor yang paling dominan adalah peran guru dan kepala sekolah. Dalam kontens kultur sekolah guru memililki peran yaitu sebagai pendidik, teladan, motivator, dan pembimbing.

Ketiga, penilaian: dalam aktualisasi pendidikan karakter di sekolah dilakukan kegiatan penilaian yang bertujuan untuk mengetahui tingkat kompetensi sikap siswa yang meliputi kognisi, afeksi, dan konasi dengan menggunakan rubrik penilaian/catatan observasi dan tindak lanjut. Nilai-nilai karakter yang telah diaktualisasikan dengan baik dalam perilaku sehari-hari siswa di Sekolah Muhammadiyah Se-Kecamatan Juntinyuat Kabupaten Indramayu adalah nilai demokrasi, religius (ketaatan beribadah), kerjasama, peduli sosial, rasa hormat, dan tanggung jawab. Sedangkan nilai kejujuran dan kedisiplinan belum teraktualis-asi dengan baik karena faktor negatif dari lingkungan sosial dan media masa.

\section{Saran}

Berdasarkan hasil penelitian, pembahasan dan simpulan yang telah dipaparkan, maka beberapa saran yang peneliti kemukakan sebagai berikut: (1) dalam konteks perencanaan pembelajaran, nilai-nilai karakter yang akan dikembangkan melalui kegiatan pembelajaran harus disesuaikan dengan program sekolah dan tuntutan 
masyarakat sekitar agar tidak terjadi bias nilai; (2) membimbing peserta didik secara terus menerus, konsisten, dan sistematis untuk menumbuhkan karakter terpuji pada peserta didik; (3) peran guru dan kepala sekolah dalam pendidikan karakter agar lebih dipertahankan dan ditingkatkan lagi supaya mampu mewujudkan lulusan yang seimbang antara moral knowing, moral feeling, dan moral action; dan (4) penilaian otentik harus dilakukan secara utuh dan menyeluruh untuk mengevaluasi kompetensi moral knowing, moral feeling, dan moral action siswa. Selain itu penilaian otentik harus mampu memberikan informasi yang valid tentang perkembangan karakter siswa seutuhnya.

\section{DAFTAR PUSTAKA}

Agboola, Alex, and Kaun Chen Tsai. "Bring Character Education into Classroom." European Journal of Educational Research 1, no. 2 (2012): 163-70.

Arifin, Zainal. "Cetakan Ke 5: Evaluasi Pembelajaran Prinsip, Teknik, Prosedur." Bandung: Remaja Rosdakarya 61 (2013).

Basuki, Ismet, and M S Hariyanto. “Asesmen Pembelajaran.” Bandung, PT Remaja Rosda Karya, 2014.

Bialik, Maya, Michael Bogan, Charles Fadel, and Michaela Horvathova. "Character Education for the 21st Century: What Should Students Learn." Center for Curriculum Redesign. Boston: Massachusetts, 2015, 23-180.

Creswell, John W. "Penelitian Kualitatif \& Desain Riset Memilih Diantara Lima Pendekatan.” Yogyakarta: Pustaka Pelajar, 2015.

Damon, William. Bringing in a New Era in Character Education. Hoover Press, 2013.

Daryanto, Suryatri Darmiatun. "Implementasi Pendidikan Karakter Di Sekolah." Yogyakarta: Gava Media, 2013.

Dewantara, Ki Hadjar. "Pendidikan Dan Kebudayaan." Yogyakarta. Majelis Luhur Persatuan Taman Siswa, 1977.

Fadlillah, Muhammad. "Implementasi Kurikulum 2013 Dalam Pembelajaran Sd/Mi, Smp/Mts, \& Sma/Ma.” Yogyakarta: Ar-Ruzz Media 144 (2014): 15.

Ghony, M Djunaidi, and Fauzan Almanshur. "Metodologi Penelitian Kualitatif." Jogjakarta: Ar-Ruzz Media, 2012.

Hakim, Lukman. "Pengembangan Media Pembelajaran PAI Berbasis Augmented Reality." Lentera Pendidikan: Jurnal Ilmu Tarbiyah Dan Keguruan 21, no. 1 (2018): 59-72.

Hariyanto, Muchlas Samani. “Konsep Dan Model Pendidikan Karakter." Bandung: PT Remaja Rosdakarya Offset, 2011.

Haryati, Mimin. "Model Dan Teknik Penilaian Pada Tingkat Satuan Pendidikan." Jakarta: Gaung Persada Press, 2007.

Heri, Gunawan. "Pendidikan Karakter Konsep Dan Implementasi." Bandung: Alfabeta, 2012.

Kamaruddin, Syamsu A. "Character Education and Students Social Behavior." Journal of Education and Learning 6, no. 4 (2012): 223-30.

Koesoema, Doni. Pendidikan Karakter: Strategi Mendidik Anak Di Zaman Global. 
Jakarta: Grasindo, 2007.

Lickona, Thomas. Educating for Character: How Our Schools Can Teach Respect and Responsibility. Bantam, 2009.

_- - “The Teacher's Role in Character Education.” Journal of Education, 1997. https://doi.org/10.1177/002205749717900206.

Majid, Abdul. "Perencanaan Pembelajaran Mengembangkan Kompetensi Guru.” PT Remaja Rosdakarya. Bandung, 2011.

Maksudin, Maksudin. "Pendidikan Karakter Nondikotomik (Upaya Membangun Bangsa Indonesia Seutuhnya)." Jurnal Pendidikan Karakter, no. 2 (2013).

Maryono. "The Implementation Of Character Education Policy At Junior High Schools And Islamic Junior High Schools In Pacitan - International Journal of Education and Research PDFwww.Ijern.Com > 2015 > May-2015." International Journal of Education and Research 3, no. 5 (2015): 267-74.

Mihardi, S. "Improved Characters and Student Learning Outcomes Through Development of Character Education Based General Physics Learning Model." Education 6, no. 21 (2015): 162-71.

Moleong, J. "Lexy. 2014, Metodologi Penelitian Kualitatif, Bandung: PT." Remaja Rosdakarya, n.d.

Muhaimin. Pemikiran Dan Aktualisasi Pengembangan Pendidikan Islam. Rajawali Pers, 2011.

Mulyasa, Enco. Pengembangan Dan Implementasi Kurikulum 2013. PT Remaja Rosdakarya, 2013.

Mulyasa, H E. “Manajemen Pendidikan Karakter, Cet.” V, Jakarta: Bumi Akara, 2013, 165.

Muslich, Masnur, and Pendidikan Karakter. "Menjawab Tantangan Krisis Multidimensional, Cet. 2." Jakarta: Bumi Aksara, 2011.

Nurhidayati, Titin. "Inovasi Pembelajaran PAI Berbasis Multiple Intelligences." Jurnal Pendidikan Agama Islam (Journal of Islamic Education Studies) 3, no. 1 (2015): 23-56.

Purnama, Diana Septi. "Character Education and Personal Social Guidance Counseling and Its Effects on Personal Social Competences." JOURNAL OF EDUCATION 7, no. 1 (2014).

Rawanoko, Endrise Septine, and Wuri Wuryandani. "Implementasi Pendidikan Karakter Demokratis Melalui Pembelajaran Ppkn Pada Siswa Kelas XII." Harmoni Sosial: Jurnal Pendidikan IPS 4, no. 2 (2017): 187-96.

Rosyad, Ali Miftakhu. "Al-Afkar, Journal for Islamic Studies URGENSI INOVASI PEMBELAJARAN DALAM PENDIDIKAN AGAMA ISLAM Al-Afkar, Journal for Islamic Studies THE URGENCY OF LEARNING INNOVATION ON ISLAMIC RELIGIOUS STUDY” 3, no. 1 (2019). https://doi.org/10.5281/zenodo.2546882.

- - . "The IMPLEMENTASI NILAI-NILAI MULTIKULTURALISME MELALUI PEMBELAJARAN PENDIDIKAN AGAMA ISLAM (THE IMPLEMENTATION OF MULTICULTURALISM VALUES THROUGH LEARNING OF ISLAMIC RELIGION EDUCATION)." Risâlah, Jurnal Pendidikan Dan Studi Islam 5, no. 1 (2019): 1-18. 
Rosyad, Ali Miftakhu, and Darmiyati Zuchdi. "Aktualisasi Pendidikan Karakter Berbasis Kultur Sekolah Dalam Pembelajaran IPS Di SMP.” Harmoni Sosial: Jurnal Pendidikan IPS, 2018. https://doi.org/10.21831/hsjpi.v5i1.14925.

Soedjatmiko, Wuri. "Pendidikan Tinggi Dan Demokrasi" Dalam Menggagas Paradigma Baru Pendidikan; Demokratisasi, Otonomi, Civil Society, Globalisasi, Ed." Sindhunata. Yogyakarta: Kanisius, 2000.

Sugiyono. Metode Penelitian Pendidikan:(Pendekatan Kuantitatif, Kualitatif Dan R \& D). Alfabeta, 2008.

Waghid, Yusef. "Islamic Education and Cosmopolitanism: A Philosophical Interlude." Studies in Philosophy and Education 33, no. 3 (2014): 329-42.

Zuchdi, Darmiyati. "Humanisasi Pendidikan,(Jakarta: PT.” Bumi Aksara, 2008.

Zuchdi, Darmiyati, Zuhdan Kun Prasetya, and Muhsinatun Siasah Masruri. "Model Pendidikan Karakter Terintegrasi Dalam Pembelajaran Dan Pengembangan Kultur Sekolah.” Yogyakarta: Multi Presindo, 2013. 